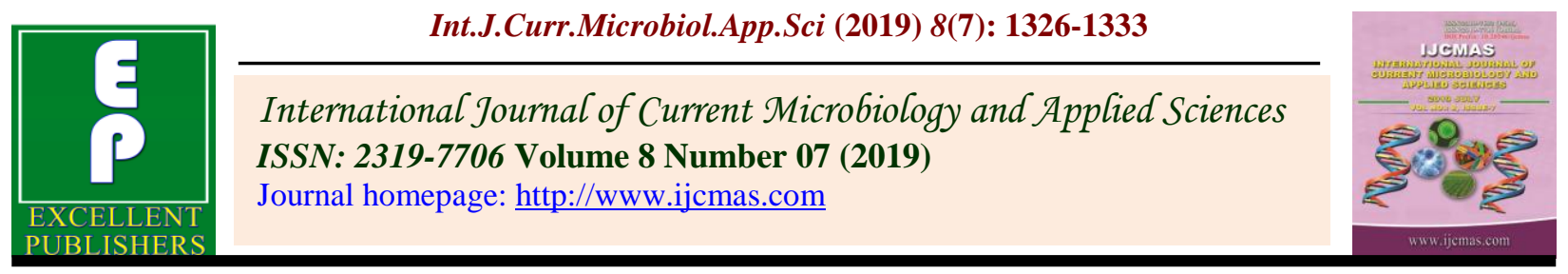

Original Research Article

https://doi.org/10.20546/ijcmas.2019.807.157

\title{
Correlation and Path Coefficient Analysis of Yield and Yield Components in Chickpea (Cicer arietinum L.)
}

\author{
P.J. Shedge", D.K. Patil and J.K. Dawane \\ Department of Agricultural Botany, College of Agriculture, Badnapur, VNMKV \\ Parbhani-431202, India \\ *Corresponding author
}

\section{A B S T R A C T}

\section{Keywords}

Chickpea,

Correlation,

Genotypic,

Phenotypic, Path

coefficient

\section{Article Info}

Accepted:

12 June 2019

Available Online:

10 July 2019
The present investigation was carried out for, "Correlation and Path Coefficient Analysis of Yield and Yield Components in Chickpea (Cicer arietinum L.)". Correlation studies showed that the traits viz. harvest index, number of pods per plant, number of secondary branches per plant, days to $50 \%$ flowering, plant height, days to maturity, number of primary branches per plant and number of seeds per pod exhibited positive and highly significant genotypic correlation with seed yield. This indicates that the simultaneous improvement of these characters through selection. Path coefficient analysis indicated that the characters viz. plant height and number of primary branches per plant exhibited negative direct effect on seed yield per plant. Hence, the selection of genotypes based on these characters as selection criterion would be helpful in improving the seed yield potential of chickpea.

\section{Introduction}

Among the pulse, the chickpea is a first important Rabi pulse crop of the region. Among all pulses chickpea contributes $36 \%$ area and 46\% production in year 2017-18. During 2017-18 estimated area and production of chickpea in Maharashtra was 18.92 lakh ha and 17.61 lakh ton respectively. In Maharashtra, highest chickpea was grown on 19.29 lakh ha with the highest production of 19.41 lakh tones during 2016-17. The productivity is also highest during 2016-17
$(1006 \mathrm{~kg} / \mathrm{ha})$. In India percentage of area is increased upto $10.81 \%$ during year 2017-18 as compared to previous year while percentage of area decreased by $4.38 \%$ in Maharashtra. Maharashtra is having $14.69 \%$ contribution in the area with $13.74 \%$ production share in the nation (average of last ten years). Madhya Pradesh is having highest area of 35.90 lakh ha, production 45.95 lakh tons and productivity $1280 \mathrm{~kg} / \mathrm{ha}$ during the year 2017 18. During 2017-18, the area in Maharashtra was 20 lakh ha with production of 17.61 lakh tons and productivity is $881 \mathrm{~kg} / \mathrm{ha}$. 
(Anonymous, 2017). In year 2018-19, Maharashtra was having 13.14 lakh ha area with production of 9.87 lakh tons and productivity is $751 \mathrm{~kg} / \mathrm{ha}$ while Marathwada is having $4.78(36 \%)$ lakh ha area under chickpea, 2.99 (35\%) tons production and 630 $\mathrm{kg} / \mathrm{ha}$ productivity. In India chickpea is exported to countries like Pakistan, Arab EMTS, Algeria, Saudi Arab and Sri Lanka and however it is imported from Australia, Russia, Tanzania, USA and Canada (Annonymous, 2018-19).

In plant breeding, correlation coefficient analysis measures the mutual relationship between various variables and determines the component characters on which selection can be based for genetic improvement in yield. Correlation coefficient is a statistical measure which is used to find out the degree (strength) and direction of relationship between two or more variables. The phenotypic and genotypic paths are commonly estimated to determine yield contributing characters which are useful for plant breeders and geneticists in selection of elite genotypes from diverse genetic population. The association of one or more characters influenced by a large number of genes is elaborated statistically by correlation coefficients. Genotypic correlation coefficient provides a measure of genotypes conjugation between characters. The method of partitioning the correlation into direct and indirect effects by path coefficients analysis was suggested by Wright (1921). It provides useful information on the relative merits of the traits in the selection criteria. Breeder selects the parents on the basis of phenotypic divergence, but for effective breeding, the knowledge of genetic diversity amongst the parents with respect to the characters which are to be improved is essential.

In applied plant breeding, the correlation and path analysis provide information on genetic association of yield and different yield contributing characters, which in turn are useful in developing breeding strategies.

\section{Materials and Methods}

The present investigation on chickpea for correlation and path analysis was conducted at Agricultural Research Station, Badnapur, during Rabi season of 2017-18. The experimental materials used for study consisted of fourty three genotypes of chickpea, out of which 25 genotypes were obtained from International Crop Research Institute for Semi-Arid Tropics, Hyderabad, 15 genotypes from the A.R.S. Badnapur and three standard checks. Forty genotypes of chickpea along with three standard checks viz. Akash (BDNG-797), Digvijay, JAKI 9218 were evaluated in a randomized block design with two replications during Rabi season of 2017-18. Each genotype was sown in two rows of $4 \mathrm{~m}$ length with spacing of $45 \mathrm{~cm}$ between rows and $10 \mathrm{~cm}$ within rows. The data were recorded on five randomly selected plants of each replication for all characters such as days to $50 \%$ of flowering, days to maturity, plant height $(\mathrm{cm})$, number of primary branches per plant, number of secondary branches per plant, number of pods per plant, number of seeds per pod, harvest index and seed yield. The genotypic covariance was calculated as per Johnson et al., (1955). To establish a cause and effect relationship the partitioning of genotypic and phenotypic correlation coefficient was done into direct and indirect effects by path analysis as suggested by Dewey and Lu (1959) and developed by Wright (1921).

\section{Results and Discussion}

\section{Correlation coefficients}

The characters viz. harvest index, number of pods per plant, number of secondary branches per plant, plant height, days to maturity and 
days to $50 \%$ flowering recorded highly positive significant correlation with seed yield. Seed yield per plant had positive significant correlation with harvest index $(\mathrm{p}=0.6975$; $\mathrm{g}=0.9968$ ) (Fig. 1). Vaghela et al., (2009) found that seed yield per plant exhibited significant and positive correlation with harvest index, number of primary branches per plant and 100 seed weight at genotypic as well as phenotypic levels. Seed yield per plant had positive significant correlation with number of pods per plant $(\mathrm{p}=0.4947 ; \mathrm{g}=0.6217)$. Earlier studies too have indicated such positive significant correlation for number of pods per plant by Guler et al., (2001). Number of secondary branches per plant $(\mathrm{p}=0.4089$; $\mathrm{g}=0.5344)$, plant height $\mathrm{cm} \quad(\mathrm{p}=0.3459$; $\mathrm{g}=0.4314$ ) also showed significant positive correlation with seed yield per plant. Arshad et al., (2004) found that seed yield had positive and significant correlation with plant height, number of pods per plant and 100 seed weight (Table 1-3).

Fig.1 Diagram showing the genotypic correlation in yield and its component characters of Chickpea

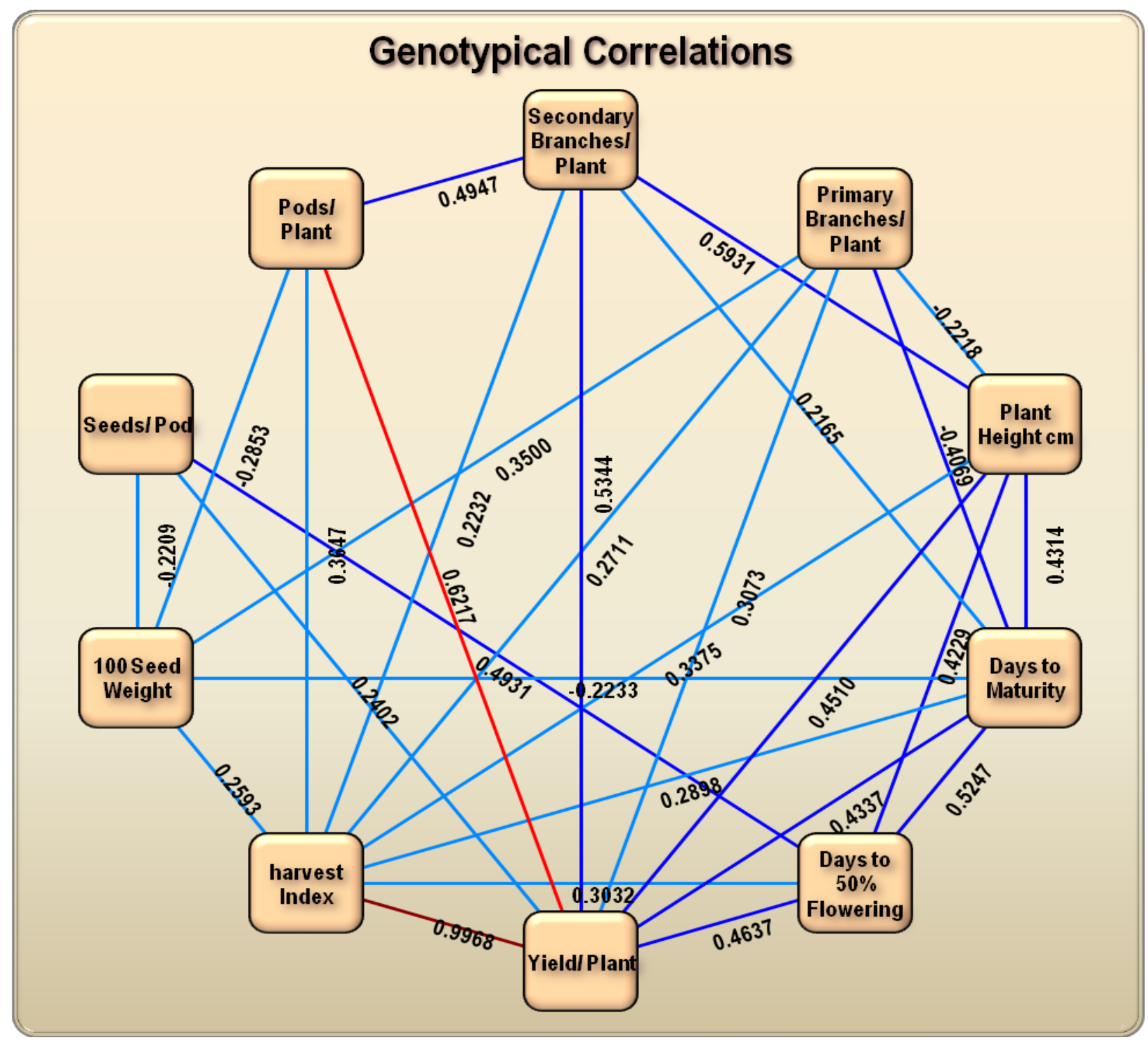


Table.1 Estimation of phenotypic (above diagonal) correlation coefficients in chickpea

\begin{tabular}{|c|c|c|c|c|c|c|c|c|c|c|}
\hline Characters & $\begin{array}{c}\text { Days to } \\
50 \% \\
\text { flowering }\end{array}$ & $\begin{array}{l}\text { Days to } \\
\text { maturity }\end{array}$ & $\begin{array}{l}\text { Plant } \\
\text { height }\end{array}$ & $\begin{array}{l}\text { Number of } \\
\text { primary } \\
\text { branches / } \\
\text { plant }\end{array}$ & $\begin{array}{c}\text { Number of } \\
\text { secondary } \\
\text { branches / } \\
\text { plant }\end{array}$ & $\begin{array}{l}\text { Number of } \\
\text { pods / } \\
\text { plant }\end{array}$ & $\begin{array}{l}\text { Number } \\
\text { of seeds / } \\
\text { pod }\end{array}$ & $\begin{array}{c}100 \text { seed } \\
\text { weight }\end{array}$ & $\begin{array}{l}\text { Harvest } \\
\text { Index }\end{array}$ & $\begin{array}{l}\text { Seed } \\
\text { yield } \\
\text { /plant }\end{array}$ \\
\hline & 1 & 2 & 3 & 4 & 5 & 6 & 7 & 8 & 9 & 10 \\
\hline $\begin{array}{l}\text { Days to } 50 \% \\
\text { flowering }\end{array}$ & 1.000 & $\begin{array}{l}0.4845 * \\
*\end{array}$ & $0.3240 * *$ & -0.0757 & 0.0920 & -0.0241 & $0.4259 * *$ & -0.0523 & $0.2902 * *$ & $0.2584^{*}$ \\
\hline Days to maturity & $0.5247 * *$ & 1.000 & $0.3459 * *$ & $-0.3480 * *$ & 0.2027 & 0.1353 & 0.0580 & -0.2112 & $0.2772 * *$ & $0.3124 * *$ \\
\hline Plant height & $0.4229 * *$ & $\begin{array}{l}0.4229 * \\
*\end{array}$ & 1.000 & $-0.3119 * *$ & $0.4712 * *$ & 0.1725 & 0.0852 & 0.1575 & $0.2743^{*}$ & $0.4045^{* *}$ \\
\hline $\begin{array}{l}\text { Number of } \\
\text { primary branches } \\
\text { per plant }\end{array}$ & -0.1380 & $\begin{array}{l}- \\
0.4069 * \\
*\end{array}$ & $-0.2218 *$ & 1.000 & 0.0659 & 0.0605 & 0.0274 & $0.2437 *$ & 0.2051 & 0.0881 \\
\hline $\begin{array}{l}\text { Number of } \\
\text { secondary } \\
\text { branches per plant }\end{array}$ & 0.1292 & $0.2165^{*}$ & $0.5931 * *$ & 0.1611 & 1.000 & $0.4548 * *$ & -0.0719 & -0.0249 & 0.1878 & $0.4089 * *$ \\
\hline $\begin{array}{l}\text { Number of pods } \\
\text { per plant }\end{array}$ & 0.0023 & 0.1398 & 0.1208 & 0.1743 & $0.4947 * *$ & 1.000 & -0.0088 & $-0.2388^{*}$ & $0.3315 * *$ & $0.4947 * *$ \\
\hline $\begin{array}{l}\text { Number of seeds } \\
\text { per pod }\end{array}$ & $0.4931 * *$ & 0.0442 & 0.0729 & -0.0084 & -0.0367 & -0.0435 & 1.000 & -0.1806 & 0.1883 & 0.1273 \\
\hline 100 seed weight & -0.0564 & $-0.2233 *$ & 0.1380 & $0.3500 * *$ & -0.0522 & -0.2853 & $-0.2209 *$ & 1.000 & $0.2344^{*}$ & 0.1883 \\
\hline Harvest index & $0.3032 * *$ & $\begin{array}{l}0.2898 * \\
*\end{array}$ & $0.3375 * *$ & $0.2711 *$ & $0.2232 *$ & $0.3647 * *$ & 0.1986 & $0.2593^{*}$ & 1.000 & $0.6975 * *$ \\
\hline $\begin{array}{l}\text { Seed yield per } \\
\text { plant }\end{array}$ & $0.4637 * *$ & $\begin{array}{l}0.4337 * \\
*\end{array}$ & $0.4510 * *$ & $0.3073 * *$ & $0.5344 * *$ & $0.6217 * *$ & $0.2402 *$ & 0.1994 & $0.9968 * *$ & 1.000 \\
\hline
\end{tabular}

* Significant at $5 \%$ level of probability or level of significance,

** Significant at $1 \%$ level of probability or level of significance 
Table.2 Direct and indirect effect of yield and its component characters on grain yield at phenotypic level

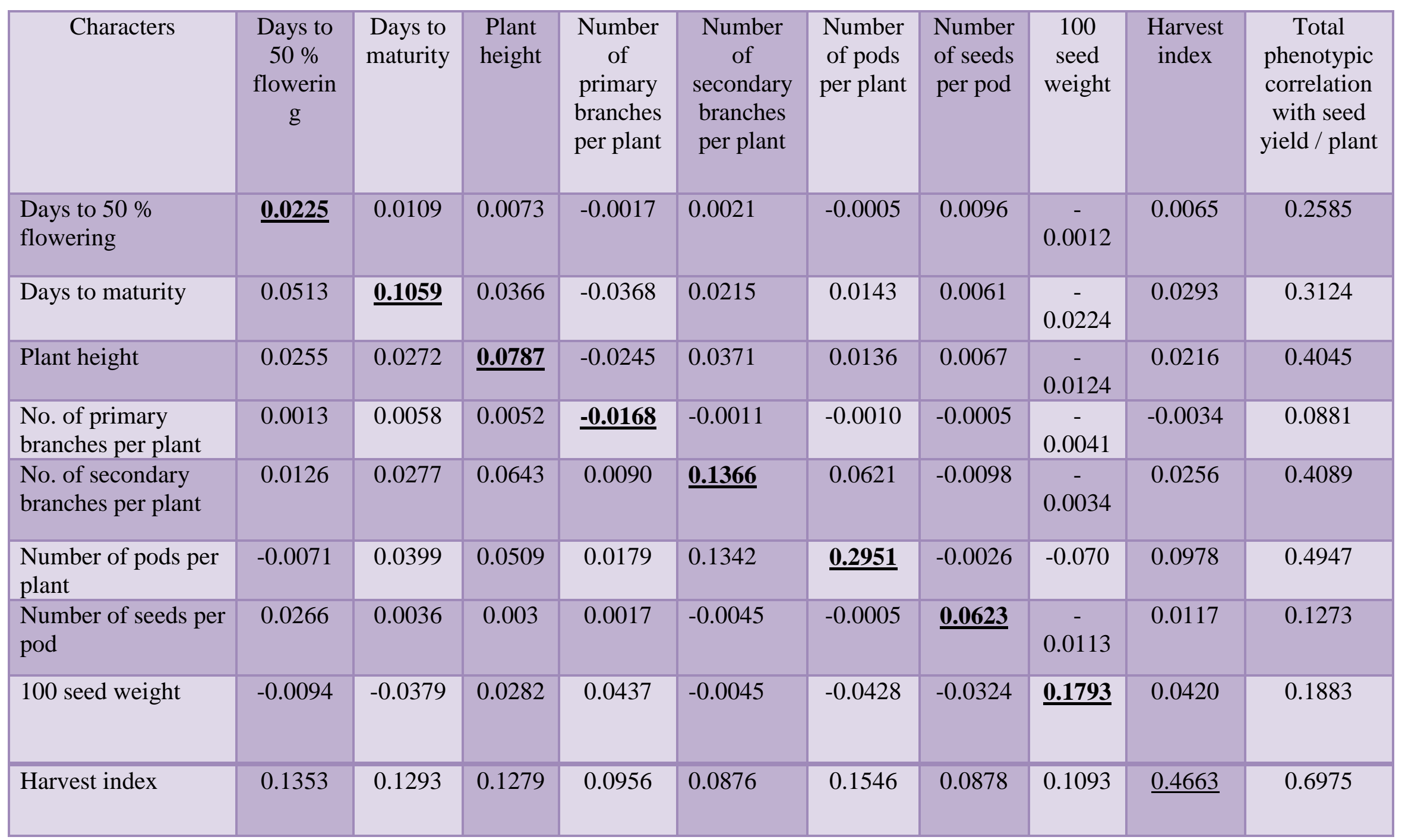

Residual effect $=0.6017$, Underlined figures indicate direct effect.

$*$, ** indicates significant at 5 and $1 \%$ level of significant respective 
Table.3 Direct and indirect effect of yield and its component characters on grain yield at genotypic level

\begin{tabular}{|c|c|c|c|c|c|c|c|c|c|c|}
\hline Characters & $\begin{array}{l}\text { Days to } \\
50 \% \\
\text { flowering }\end{array}$ & $\begin{array}{l}\text { Days to } \\
\text { maturity }\end{array}$ & $\begin{array}{l}\text { Plant } \\
\text { height }\end{array}$ & $\begin{array}{l}\text { Number } \\
\text { of } \\
\text { primary } \\
\text { branches } \\
\text { per plant }\end{array}$ & $\begin{array}{l}\text { Number } \\
\text { of } \\
\text { secondary } \\
\text { branches } \\
\text { per plant }\end{array}$ & $\begin{array}{l}\text { Number } \\
\text { of pods } \\
\text { per plant }\end{array}$ & $\begin{array}{l}\text { Number } \\
\text { of seeds } \\
\text { per pod }\end{array}$ & $\begin{array}{c}100 \\
\text { seed } \\
\text { weight }\end{array}$ & $\begin{array}{l}\text { Harvest } \\
\text { index }\end{array}$ & $\begin{array}{c}\text { Total } \\
\text { genotypic } \\
\text { correlation } \\
\text { with seed } \\
\text { yield / plant }\end{array}$ \\
\hline Days to maturity & 0.0690 & $\underline{0.1315}$ & 0.0567 & -0.0535 & 0.0285 & 0.0184 & 0.0058 & $\begin{array}{c}- \\
0.0294\end{array}$ & 0.0381 & 0.4337 \\
\hline Plant height & -0.0772 & -0.0787 & - & 0.0405 & -0.1082 & -0.0220 & -0.0133 & $\begin{array}{c}- \\
0.0252\end{array}$ & -0.0616 & 0.4510 \\
\hline $\begin{array}{l}\text { Number of pods per } \\
\text { plant }\end{array}$ & 0.0006 & 0.0358 & 0.0309 & 0.0446 & 0.1267 & $\underline{0.2561}$ & -0.0111 & $\begin{array}{c}- \\
0.0731\end{array}$ & 0.0934 & 0.6217 \\
\hline $\begin{array}{l}\text { Number of seeds per } \\
\text { pod }\end{array}$ & 0.0374 & 0.0034 & 0.0055 & -0.0006 & -0.0028 & -0.0033 & $\underline{0.0758}$ & $\begin{array}{c}- \\
0.0167\end{array}$ & 0.0151 & 0.2402 \\
\hline 100 seed weight & -0.013 & -0.0407 & 0.0251 & 0.0638 & -0.009 & -0.020 & -0.0402 & $\underline{0.1822}$ & 0.0472 & 0.1994 \\
\hline Harvest index & 0.2261 & 0.02161 & 0.2517 & 0.2022 & 0.1664 & 0.2720 & 0.1481 & 0.1934 & $\underline{0.7458}$ & 0.9968 \\
\hline
\end{tabular}


The charaters viz. days to maturity $(\mathrm{p}=0.3124$; $\mathrm{g}=0.4337)$ and days to $50 \%$ flowering $(\mathrm{p}=0.2584 ; \mathrm{g}=0.4637)$ also recorded highly positive significant correlation with seed yield. In other words, an increase in the magnitude of these characters would lead to an increase in the magnitude of grain yield.

\section{Path analysis}

In path coefficient analysis the characters, harvest index, number of pods per plant, number of secondary branches per plant, days to maturity and days to $50 \%$ flowering had positive direct effect on seed yield in decreasing order of magnitude. Among all the components number of harvest index exhibited the highest direct effect $(\mathrm{p}=0.4663)$ on seed yield followed by number of pods per plant $(\mathrm{p}=2951), 100$ seed weight $(\mathrm{p}=0.1793)$, number of secondary branches per plant $(\mathrm{p}=0.1366)$, days to maturity $(\mathrm{p}=0.1059)$, plant height $(\mathrm{p}=0.0787)$, seeds per pod $(\mathrm{p}=0.0623)$, days to $50 \%$ flowering $(\mathrm{p}=0.0225)$, while primary branches $(\mathrm{p}=-$ 0.0168 ) recorded negative direct effect at phenotypic level. Similar results were reported by Talebi et al., (2007) for number of pods per plant, number of seeds per pod and harvest index.

At genotypic level harvest index exhibited the highest positive direct effect $(\mathrm{g}=0.7458)$ on seed yield followed by secondary branches per plant $(\mathrm{g}=0.3133)$. Zali et al., (2011) recorded number of secondary branches per plant, plant height had positive direct effect on seed yield. The characters viz. number of pods per plant $(\mathrm{g}=0.2561), 100$ seed weight $(\mathrm{g}=0.1822), \quad$ days to $50 \%$ flowering $(\mathrm{g}=0.1754)$, days to maturity $(\mathrm{g}=0.1315)$, number of seeds per pod ( $\mathrm{g}=0.0758)$ exhibited the highest positive direct effect and negative direct effect by number of primary branches per plant $(\mathrm{g}=-0.0159)$ and plant height $(\mathrm{g}=-$ 0.1825). Thakur and Sirohi (2009) reported highest positive direct effect of harvest index and number of pods per plant on grain yield. These findings revealed that these were major yield contributing traits in chickpea. Path coefficient analysis indicated that the characters viz., plant height and number of primary branches per plant exhibited negative direct effect on seed yield per plant. But these characters had positive indirect effect via. another character on seed yield. Hence, the selection of genotypes based on these characters as selection criterion would be helpful in improving the seed yield potential of chickpea.

\section{References}

Arshad M., A. Bakhsh, and Ghafoor A., 2004. Path coefficient analysis in chickpea under rainfed condition. Pak. J. Bot. 36: 75-81.

Dewey, D.R. and Lu, K.H. 1959. A correlation and path coefficient analysis of component of Wheat grass seed production. Agron. J., 51: 515-518.

Guler, M., Adak, M.S. and Ulukah, H. 2001. Determining relationship among yield and some yield components using path coefficient analysis in Chickpea. European J. Agron., 14(2): 161-166.

Johnson, H.W., Robinson, H.F. and Comstock, R.E. 1955. Genotypic and phenotypic correlation in soybean and their implications in selection. Agron. J., 47: 477-482.

Talebi, R., Faydz, F. and Jelodar, A. 2007. Correlation and path coefficient analysis of yield and yield components of Chickpea under dryland condition in west of Iran. Asian J. of Plant Sci., 6 (7): 1151-1154.

Thakur S. and Sirohi A. (2009). Correlation and path analysis in chickpea under different seasons. Legume Res., 32(1): 1-6. 
Vaghela M.D., Poshiya V.K., Savaliya V.K., Davada B.K. and Mungra K.D. 2009. Studies on character association and path analysis for seed yield and its components in chickpea (Cicer arietinum L.) Legume Res.; 32(4); 245249.
Wright, S. 1921. Correlation and causation. $J$. Agric. Re., 20: 557-565.

Zali, H., Farshadfarb E. And Sabaghpour S. H. 2011. Genetic variability and interrelationships among agronomic traits in chickpea (Cicer arietinum L.) genotypes. Crop Breed. J. 1(2):127-132.

\section{How to cite this article:}

Shedge, P.J., D.K. Patil and Dawane, J.K. 2019. Correlation and Path Coefficient Analysis of Yield and Yield Components in Chickpea (Cicer arietinum L.).

Int.J.Curr.Microbiol.App.Sci. 8(07): 1326-1333. doi: https://doi.org/10.20546/ijcmas.2019.807.157 